\title{
The Gene Frequency of Acute Werdnig-Hoffmann Disease (SMA Type 1). A Total Population Survey in North-East England
}

\author{
JOHN H. PEARN \\ Muscular Dystrophy Group Research Laboratories, Newcastle General Hospital, \\ Westgate Road, Newcastle upon Tyne NE4 6BE
}

\begin{abstract}
Summary. A retrospective total population study of acute Werdnig-Hoffmann disease (spinal muscular atrophy type 1) has been undertaken in three counties of North-East England (Northumberland, Newcastle upon Tyne, and Durham). The gene frequency for the disease is $q=0.00625$ with a carrier frequency for this part of the English population of 1 in 80 . The data suggest that there may be differences in gene frequency within the region sampled, a finding in keeping with other investigations of variations in gene frequency in this region. The suggestion that this disease is the second most common fatal autosomal recessive disease of childhood in Britain is confirmed. An hypothesis of heterozygote advantage due to relative resistance to epidemic poliomyelitis is presented to account for the high gene frequency observed.
\end{abstract}

It has previously been established that the carrier frequency for acute Werdnig-Hoffmann disease is in the probable range of 1 in 60 to 1 in 90 in the English population (Pearn, Carter, and Wilson, 1973), a finding consistent with the clinical impression that this disease is the second or third most common fatal recessive disease of childhood in Britain (Roberts, Chavez, and Court, 1970; Carter, 1972).

Earlier attempts to measure gene and carrier frequencies directly have not been possible for two reasons. First, the degree of selection occurring before referral to big centres is considerable; more importantly, the extent of such selection has been quite unknown. This difficulty is common to all studies of diseases which are fatal in infancy. Secondly, large centres offering the sophisticated diagnostic (electromyography, histochemistry, etc), supportive (consultant paediatricians, neurologists, and geneticists), and administrative (regional medical records and reliable retrieval systems) facilities necessary for the definition of index cases, tend to draw on primary populations whose size, composition and extent are not precisely known. The pri-

Received 9 May 1973. mary population from which patients are drawn varies from disease to disease depending on such factors as the reputation of local centres and their consultants for specific diseases, ease of travel and a miscellany of other interacting influences. For these reasons, direct measurements of gene frequencies for recessive conditions are practicable in only relatively few instances (eg, see Danks, Allan, and Anderson, 1964/65, in the instance of cystic fibrosis).

In the population of North-East England there are several factors which afford the opportunity to measure directly the gene frequency of acute Werdnig-Hoffmann disease (SMA type 1 of Emery, 1971a) with comparative accuracy. There are four factors which have facilitated this.

1. The existence of a diagnostic and management centre of world reputation for neuromuscular disease* means in practice that local patient movement is centripetal to this centre.

2. Population densities are so distributed (Fig. 1) that a large rural buffer-zone encircles an area of

- The Regional Neurological Centre and Muscular Dystrophy Group Research Laboratories, Newcastle General Hospital, Newcastle upon Tyne. 


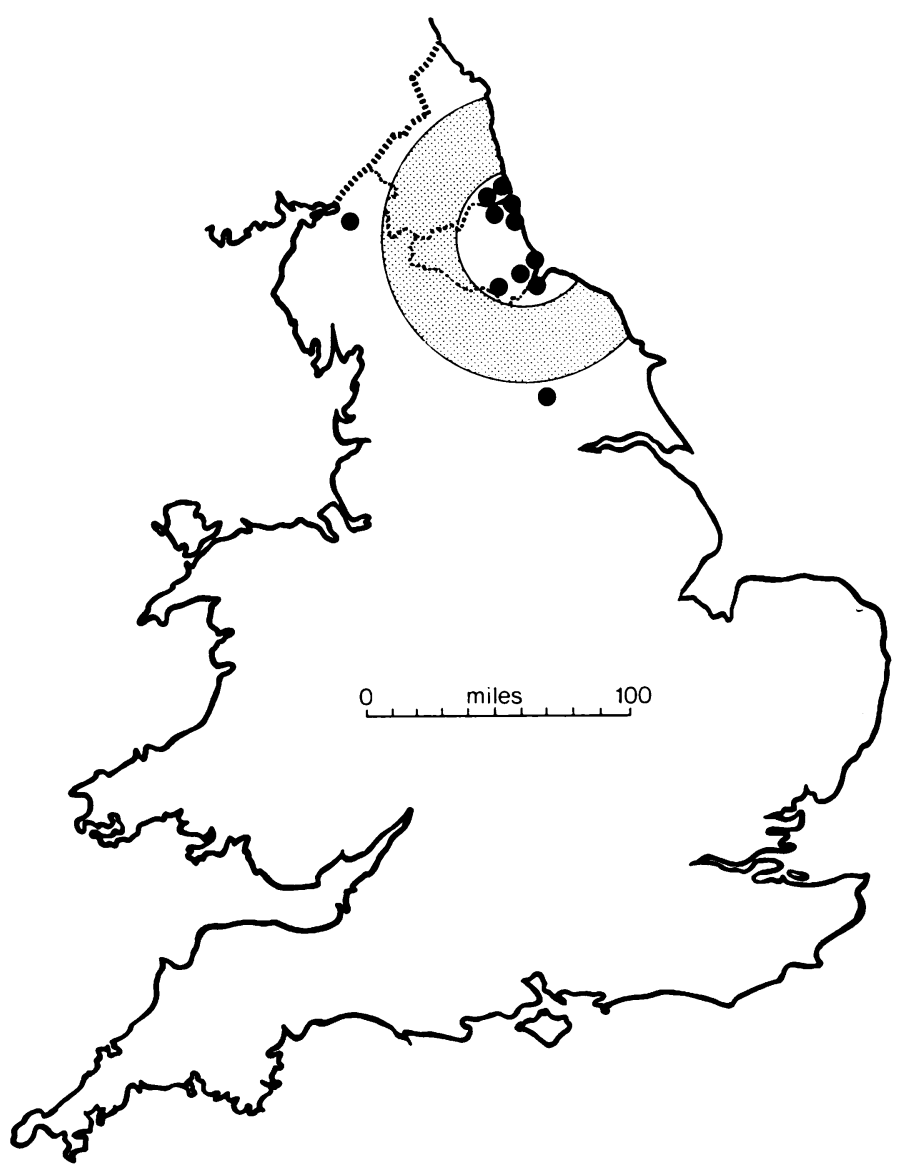

Fig. 1. Map showing the counties of Northumberland and Durham (dotted lines) and the conurbations of Tyneside and Teesside. Patients were chosen from the geographical area of the three counties within the dotted lines (Northumberland, Newcastle upon Tyne, and Durham). Towns in the area with populations over 50,000 are shown by large black circles. It can be seen that a rural buffer-zone (shaded area) surrounds and defines the two major conurbations.

(From Moser and Scott, 1961.)

high population density. This latter comprises the combined two major conurbations of Tyneside and Teesside. As a general rule, patients tend not to cross, or not to be referred across, such a zone to seek diagnosis and management elsewhere.

3. The degree of professional interaction and cooperation (see the acknowledgements below) has been such that it has been possible for one worker to retrieve the records of every case diagnosed as acute Werdnig-Hoffmann disease in the North-East region over the past 13 years.

4. Historically, the population of the area has been relatively stable. More importantly, the population has been extensively studied and many demographic (Moser and Scott, 1961; General Register Office, 1963; House and Knight, 1965; House, 1967), genetic (Roberts, 1953; Papiha and Roberts, 1972; Dobson, 1973; Roberts, 1973), and medico-social (Miller et al, 1960; Russell et al, 1963;
Neligan and Prudham, 1969; Bulmer, 1970; Donaldson, 1972) characteristics defining it are known for the temporal period under review.

Items 1,2 , and 3 above mean in effect that it has been possible to undertake a complete total population study of this disease and of its associated gene frequency in this area. Item 4 allows the interpretation of the results with considerable specificity. This paper reports the results of this total population survey to measure directly the gene frequency of this disease.

\section{Methods}

Diagnosis. Index cases were considered as acute infantile Werdnig-Hoffmann disease (spinal muscular atrophy-SMA type 1) if (a) clinical features were indicative of or compatible with the diagnosis (Byers and Banker, 1961; Pearn and Wilson, 1973), (b) muscle biopsy or necropsy histology revealed denervation 
TABLE I

SELECTION OF INDEX CASES FROM ALL CASES OF ACUTE WHD KNOWN TO THE REGIONAL NEUROLOGICAL CENTRE, NEWCASTLE UPON TYNE

Patients in gene frequency survey

Patients of non-English parents

English patients normally resident outside the three counties

English patients qualifying residentially but born outside 1966-71 period

Total (20 families)

$\begin{array}{r}9 \\ 2 \\ 8 \\ 8 \\ \hline 27\end{array}$

atrophy, (c) electromyography had been performed in at least one member of each affected sibship with evidence both of denervation and of corresponding normal nerve conduction times, and (d) the child had died by 3 years of age (Pearn et al, 1973; Pearn and Wilson, 1973).

Series. Patients with acute Werdnig-Hoffmann disease have been obtained from records dating back over the past 13 years. However, ascertainment can be confidently regarded as complete only since 1965 when computerized retrieval systems were instituted in the North-East region. Because of an inevitable lapse of time between diagnosis and cataloguing, this study considered only the 6-year period from 1966 to 1971 . Only cases born to English parents were included; this necessitated the exclusion of two families, one from Pakistan and one from the Lebanon. Cases were considered as index cases only if they occurred in families normally resident in one of the three administrative counties of Durham, Newcastle upon Tyne, and Northumberland. This necessitated the exclusion of a further seven affected families who had been referred from other parts
of Britain.

Selection. Cases were found by reference to (a) the case register of the Regional Neurological Centre, Newcastle General Hospital, (b) the biopsy register with- $\vec{D}$ in the Muscular Dystrophy Group Research Labora- $\bar{C}$ tories, (c) the computed diagnostic register for the three Counties held by the Statistics Section, Newcastle Regional Hospitals Board, (d) individual hospital diagnostic registers of those hospitals within the three counties with specialist paediatric facilities, (e) from the records of the Department of Human Genetics, University of Newcastle upon Tyne, and (f) by individual representation to each of the 16 paediatricians of the region and to selected neurologists. It was hoped that such ascertainment would give mutually inclusive data, and this turned out to be the case.

Interview. Parents of patients were interviewed and a full genetic kindred obtained.

Population Data. Information about the general population from which patients were drawn was obtained by reference to the 1961 Census data and from the extensive published work on the demography of this population (eg, House and Knight, 1965; House, 1967). Specific details about total birth-rate were obtained from the 10 Medical Officers of Health in the three counties.

\section{Results}

A total of 27 patients (from 20 families) with acute Werdnig-Hoffmann disease (SMA type 1)

DETAILS OF PATIENTS (9 INDE

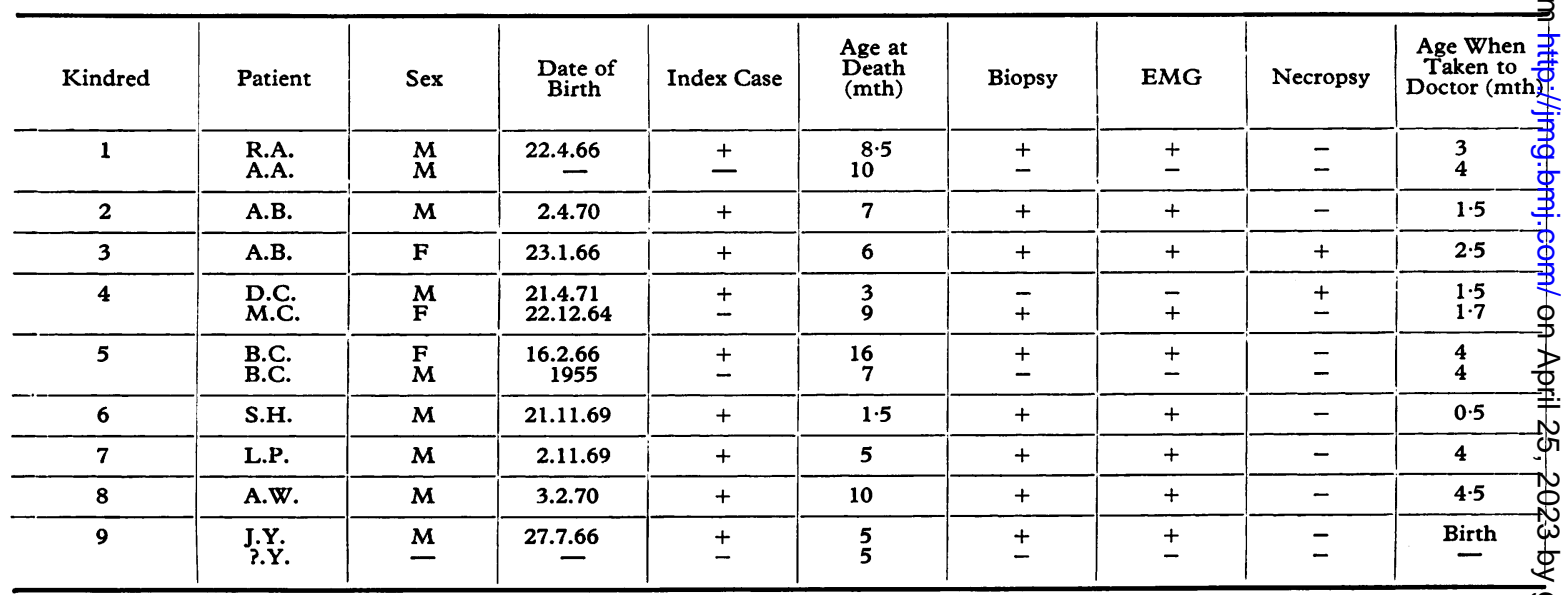

* Consanguinity denied but elements of both maternal and paternal ancestry came from same village region. A total population survey of all live births in three North-East counties during the period 1966-71 inclusive. 
TABLE III

BIRTH FREQUENCY OF ACUTE WHD

\begin{tabular}{l|c|c}
\hline \multicolumn{1}{c|}{ County } & $\begin{array}{c}\text { Total } \\
\text { Live } \\
\text { Births }\end{array}$ & $\begin{array}{c}\text { Index } \\
\text { Cases of } \\
\text { Acute WHD }\end{array}$ \\
\hline \begin{tabular}{l|l} 
Northumberland \\
Newcastle upon Tyne
\end{tabular} & 50,922 & 1 \\
Durham & 158,549 & 0 \\
Total & 231,370 & 8 \\
\hline
\end{tabular}

Incidence is 1 per 25,708 live births. Figures from three counties for the six-year period 1966-71 inclusive. Birth figures from County Medical Officers of Health Statistics.

are known to have been treated in the area served by the Newcastle Regional Hospitals Board since 1959. As the total population study was considered complete only for the period 1966 to 1971 inclusive, patients were taken only from this period; the selection introduced thereby is shown in Table I. Details of the nine patients in this period are shown in Table II. These patients had four affected sibs but all were born outside the survey period. One family declined to be interviewed, and one family remained untraceable in spite of considerable effort. Reliable data about these two families, was, however, available from other sources. It can be seen (Table II) that clinical features of all cases do not differ from the general clinical picture of the disease (Pearn and Wilson, 1973). No consanguinity was found among any of the parents in any of the 20 families, a finding in keeping with the prior knowledge that the gene involved is a relatively common one. However, in three of the index families in this study, elements of both maternal and paternal ancestry came from the same village region. There were, however, no common surnames among the four grandparents of each of the nine index cases. Details of birth frequencies for the three administrative counties are shown in Table III.

The incidence of the disease is 1 per 25,708 live births, yielding a carrier frequency of 1 in 80 and a gene frequency of 1 in $160(q=0.00625)$. For the population studied this must be a minimum estimate. The high ratio (4:5) of two-sib-affected families to isolated cases is also suggestive that isolated cases of acute Werdnig-Hoffmann disease are being missed, even under these relatively optimal conditions of diagnosis and case finding. Such shortcomings occur unavoidably in all fatal infantile diseases (Danks et al, 1964/65). If this survey in the North-East is considered as a sample of the wider English population, 95\% confidence limits for q are 0.00593 to 0.00657 . As all cases of acute Werdnig-Hoffmann disease are probably diagnosed by 18 months ( $95 \%$ being dead by this age-Pearn and Wilson, 1973), no correcting factor for undiagnosed cases which might present in the future has been necessary in this study, as would be the case for the more chronic forms of SMA.

None of the 29 first-cousin sibships (101 first

II

CASES) WITH ACUTE WHD

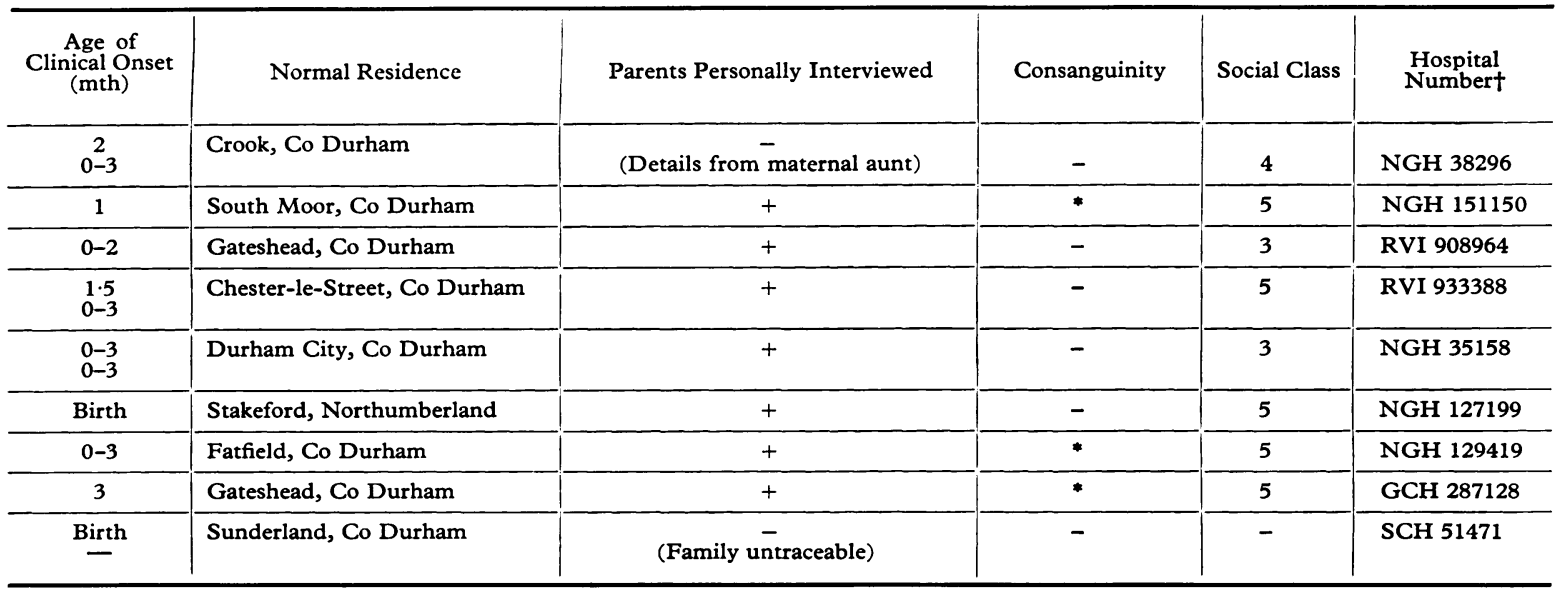

$+\mathrm{NGH}=$ Newcastle General Hospital; RVI = Royal Victoria Infirmary; GCH = Gateshead Children's Hospital; SCH = Sunderland Children's Hospital. 
cousins) of investigated index cases contained an affected member. The use of traditional methods employing affected first-cousin incidence rates to determine gene frequency is notoriously difficult in cases where the life expectancy of the disease exceeds one year in only a small minority of cases.

\section{Discussion}

Accurate data for calculating gene frequencies of recessive disorders fatal in infancy are difficult to obtain. Gene frequency estimates from birth incidence figures presuppose no altered foetal mortality due to the gene, either in the heterozygote or homozygote state. A search for spontaneous sib abortions in an earlier large series of kindreds with acute Werdnig-Hoffmann disease (Pearn et al, 1973) suggests that late fetal loss at least is not increased in this disease. In addition, appraisal of the frequency distribution curve for age-at-death in a large clinical series (Pearn and Wilson, 1973) suggests that death before two months of age is the exception (see also Table II).

From Table III it can be seen that an apparently high gene frequency for acute Werdnig-Hoffmann disease exists in County Durham (for County Durham taken in isolation $q=0.00714$ ). There are three possible explanations to account for this. First, it may represent a true elevated gene frequency in this geographical area. Unpublished data from an earlier large survey based in London suggest that geographical differences in gene frequency exist, particularly with respect to a high incidence in Ireland. As far as the North-East region of England is concerned, it is known that several normal genetic conditions vary significantly from locality to locality. ABO blood groups (Roberts, 1953; Kopéc, 1970) and PTC tasting (Sunderland, 1970) but not adenosine deaminase (Papiha and Roberts, 1972) gene frequencies show significant local variations in the region. Local gene frequency variation within Northumberland is not surprising in view of the ingenious surveys of Dobson (1973) and Rawling (1973) who used marriage records and surname analysis to provide evidence that Northumberland parishes in recent historical times contained different and partially isolated genetic populations. Whether such geographical differences in the gene frequency of acute Werdnig-Hoffmann disease is also a real phenomenon must await results of a prospective survey. In view of the above evidence, however, and in the light of other genetic differences such as skin colour within the region (Hulse, 1973), it would be surprising if such differences did not exist.
Secondly, the apparent elevation may be due to differential consanguinity rates in County Durham. There is little evidence for this but estimates of inbreeding coefficients certainly vary among nineteenth century Northumberland parishes (Rawling, 1973). The third possibility is that the methods of ascertainment available are such that cases occurring in the County of Northumberland are being missed. Naturally by the nature of the present study it is impossible to tell whether this is so, but the author thinks that this is the least likely of the three possibilities. This high estimate of the gene frequency of this disease differs from the findings of Zellweger, Hanhart, and Schneider (1972) who have felt that the gene frequency is not higher than that of other autosomal recessive conditions, at least in Switzerland.

If the estimate of gene frequency is correct for this population $(q=0.006)$, this is rather high for a lethal disease with zero fitness (see the comparative tables of the recessive gene frequencies given by Roberts et al [1970] and Emery [1971b]). If it is assumed that there is no heterozygote advantage, but the population is randomly mating, and that homozygote fitness is zero, then the calculated mutation rate is $3.906 \times$ $10^{-5}$. This is within the range of variation observed for autosomal recessives, though rather high (Morton, Crow, and Muller, 1956). As there is ne known reason why such a mutation rate should be selectively high, one should perhaps consider other possibilities. One such is that it merely reflects the population subdivisions; another is the possibility of heterozygote advantage with increased fitness. It is interesting to speculate about this possibility. If a subtle genetically determined biochemical change exists in the anterior horn cell of heterozygotes, it may well protect against a disease such as paralytic poliomyelitis. It is known that the polio virus demands a highly specific biochemical milieu in which to grow (Eagle, 1959) and it may well be that subtle intracellular differences in anterior horn cell biochemistry protect against polio invasion. Such an hypothesis is purely speculative, of course, but it is in keeping with the themes of heterozygote advantage developed for sickle cell anaemia (Allison, 1954) and cystic fibrosis (Crawfurd, 1972), and suggests further investigation.

The author wishes to thank Professor J. N. Walton for providing the facilities of the Muscular Dystrophy Group Research Laboratories, and for his continual encouragement; also Dr D. F. Roberts and Professor John House of the University of Newcastle upon Tyne; and the consultant paediatricians and neurologists, especially Dr David Gardner-Medwin and Dr Malcolm Campbell 
of the North-East for access to their patients; and Dr Cedric Carter of the MRC Clinical Genetics Unit, London. Mr Derek Brown and all Medical Officers of Health of the North-East Hospitals Region personally provided statistical data which made this project possible. The generous financial support of the Florey Fellowship, The Royal Society, is gratefully acknowledged.

\section{REFERENCES}

Allison, A. C. (1954). Protection afforded by sickle cell trait against subtertian malarial infection. British Medical fournal, 1, 290-294.

Bulmer, M. I. A. (1970). Social structure and social change in the twentieth century. In Durham County and City with Teesside, ed. by J. C. Dewdney, pp. 417-432. Local Executive Committee of the British Association, Durham.

Byers, R. K. and Banker, B. Q. (1961). Infantile muscular atrophy. Archives of Neurology, 5, 140-164.

Carter, C. O. (1972). MRC Clinical Genetics Unit, London. Personal communication.

Crawfurd, M. d'A. (1972). Meeting of the Genetical Society, Leeds. Personal communication.

Danks, D. M., Allan, J., and Anderson, C. M. (1964/1965). A genetic study of fibrocystic disease of the pancreas. Annals of Human Genetics, 28, 323-356.

Dobson, T. (1973). Historical population structure in Northumberland. In Genetic Variations in Britain, ed. by D. F. Roberts and E. Sunderland, pp. 67-82. Taylor and Francis, London.

Donaldson, R. J. (1972). Infant Mortality in Teesside. Teesside Health Department, Middlesbrough.

Eagle, H. (1959). Amino acid metabolism in mammalian cell cultures. Science, 130, 432-437.

Emery, A. E. H. (1971a). The nosology of the spinal muscular atrophies. Fournal of Medical Genetics, 8, 481-495.

Emery, A. E. H. (1971b). Elements of Medical Genetics, 2 nd edition, p. 151. E. and S. Livingstone, Edinburgh.

General Register Office, UK (1963). County report, Northumberland, Durham. In Census 1961 England, Wales, pp. 15-16. HMSO, London.

House, J. W. (1967). General summary. In Mobility and the North, vol. 1. North Regional Planning Committee of Local Government, Newcastle upon Tyne.

House, J. W. and Knight, E. M. (1965). Migrants of North-East England 1951-61. Character, age and sex. In Papers on
Migration and Mobility in Northern England, No. 2. University of Newcastle upon Tyne, Series 1.

Hulse, F. S. (1973). Skin colour in Northumberland. In Genetic Variations in Britain, ed. by D. F. Roberts and E. Sunderland, pp. 245-258. Taylor and Francis, London.

Kopeć, A. (1970). The distribution of the blood groups in the United Kingdom. In Oxford Monographs on Medical Genetics, pp. 44-45. Oxford University Press, London.

Miller, F. J. W., Court, S. D. M., Walton, W. S., and Knox. E. G. (1960). Growing up in Newcastle upon Tyne. Oxford University Press, London.

Morton, N. E., Crow, J. F., and Muller, H. J. (1956). An estimate of the mutational damage in man from data on consanguineous marriages. Proceedings of the National Academy of Sciences of the $U S A, 42,855-863$.

Moser, C. A. and Scott, W. (1961). British Towns. A Statistical Study of their Social and Economic Differences, 1st edition, pp. ii, 36 and 94, Oliver and Boyd, London.

Neligan, G. and Prudham, D. (1969). Norms for four standard developmental milestones by sex, social class and place in family. Developmental Medicine and Child Neurology, 11, 413-422.

Papiha, S. S. and Roberts, D. F. (1972). Adenosine deaminase (ADA) polymorphism in Northern England. Humangenetik, 15, 279-281.

Pearn, J. H., Carter, C. O., and Wilson, J. (1973). The genetic identity of acute infantile spinal muscular atrophy. Brain. (In press.)

Pearn, J. H. and Wilson, J. (1973). Acute infantile spinal muscular atrophy. Archives of Disease in Childhood. (In press.)

Rawling, C. P. (1973). A study of isonymy. In Genetic Variations in Britain, ed by D. F. Roberts and E. Sunderland, pp. 83-94. Taylor and Francis, London.

Roberts, D. F. (1973). Reader in human genetics, University of Newcastle upon Tyne. (Personal communication.)

Roberts, D. F., Chavez, J., and Court, S. D. M. (1970). The genetic component in child mortality. Archives of Disease in Childhood, 45, 33-38.

Roberts, J. A. F. (1953). An analysis of the blood-group records of the North of England. Hereditary, 7, 361-388.

Russell, J. K., Fairweather, D. V. I., Millar, D. G., Brown, A. M., Pearson, R. C. M., Neligan, G. A., and Anderson, G. S. (1963). Maternity in Newcastle upon Tyne: a community study. Lancet, 1, 711-713.

Sunderland, E. (1970). Some genetic characteristics. In Durham County and City with Teesside, ed. by J. C. Dewdney, pp. 379-391. Local Executive Committee of the British Association, Durham.

Zellweger, H., Hanhart, E., and Schneider, H. J. (1972). A new genetic variant of the spinal muscular atrophies in infancy. fournal of Medical Genetics, 9, 401-407. 